\title{
Sipping a bit of science
}

\author{
Laura Benzonana and Nikos Sgantzis reflect on their experience as organizers for Pint of Science in Greece.
}

Y ou don't need to be a scientist to have scientific curiosity. Be it to impress friends during a dinner party, or to know more about the latest technologies or health issues, everyone has science-related questions. With Google Assistant, Siri or Alexa always at our beck and call, it is not so difficult to find some sort of answer on the internet; but this also exposes us to every type of unbelievable conspiracy theory, not backed up by any scientific evidence.

How about asking a scientist then? Are they a different species locked away in their labs and unapproachable by people? Or are they happy to mingle with anyone with a scientific curiosity, in a forum that invites to connect, discuss and debate?

Enter Pint of Science. In 2013, while performing experiments in a lab at Imperial College in London where they were both doing a postdoc, Praveen Paul and Michael Motskin were discussing the limited number of occasions researchers have to interact with people genuinely interested in what goes on in a lab. They decided to fill this gap with Pint of Science, an opportunity for everyone to discuss the latest research findings with experts while having a drink. In 2013 they organized 45 events in London, Oxford and Cambridge ${ }^{1,2}$. The network grew rapidly in the next few years, with events hosted by bars and cafes all around the world. In 2019, nearly 3,000 events were hosted in 400 cities across 24 countries, attracting 140,000 attendees. Such a large success definitely shows how much scientists enjoy sharing their work with people thirsty for knowledge.

In 2019 we had the opportunity to be part of the organizing team of Pint of Science in Greece. One of us, Laura, had just moved back to Greece after having spent 16 years in London. Nikos joined from a different path, deciding to become an organizer after his positive experience in 2018 as one of the festival's speakers in Athens.

We were both aware of the particular challenges posed by the current economic environment in Greece. In a scenario where investments in scientific information are limited by the financial crisis, science communication becomes an important alternative form of accessible education, as well as a welcome distraction to everyday struggles. For us, avoiding an entrance fee - which is used in some other countries

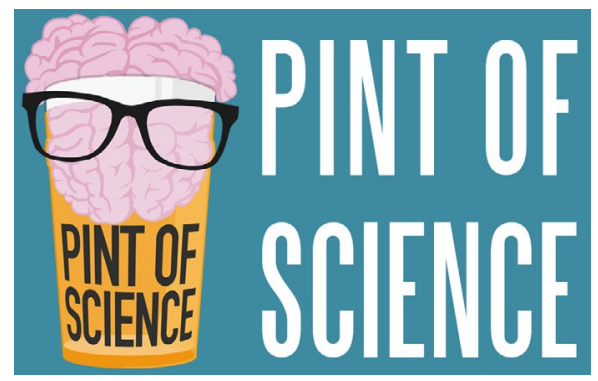

Credit: courtesy of Pint of Science

- was essential to make sure that anyone craving knowledge was allowed to access it. This meant that securing alternative funds for the event was certainly a major concern for us. Support from universities and central government would have been hard to achieve, so in the first year we relied mainly on our own personal networks of local organizations and businesses. In the second year, scientific societies also chipped in and the budget increased.

Another issue we faced was getting the teams to work on the organization and delivery of the festival. In the UK, the festival is largely organized by postdocs, lecturers, public engagement departments and funded $\mathrm{PhD}$ students. In contrast, in Greece $\mathrm{PhD}$ students rarely get a salary for their $\mathrm{PhD}$, so they often have additional jobs to support themselves. In fact, all members of our Pint of Science team have full-time jobs and we had to rely on our limited free time and our passion - something that the financial crisis has not taken away from the Greeks - to keep ourselves focused on the event organization.

The team's next step was to find the right speakers, scientists that were able to translate their technical jargon into a presentation that everyone could understand and enjoy. We wanted to show that Greece is still an important hub of innovation and research, and an inspirational place for young entrepreneurs. A great variety of topics were covered in the talks, such as artificial intelligence, cancer, tropical diseases, space exploration, psychology and even management of human resources; these certainly well represented the broad interests and potential of the Greek scientific community. The speakers adapted well to a form of scientific communication departing from traditional university lectures. Talks requiring audience participation were particularly appreciated, such as the live demonstration of a machinelearning algorithm distinguishing apples from oranges performed by George Gianakopoulos from the research centre Demokritos in Athens, or the detection of blood from a piece of tissue shown by Nikos. Debates at the end of each talk were always very lively; for instance, the talk by Christina Giannopapa (head of political affairs, European Space Agency) on the space 4.0 era attracted a question from every single member of the audience. It was wonderful to see all the speakers happy to stick around after their allotted time slots, sharing a drink with the public and continue discussing. Overall, in Greece we held nearly 50 events with about 100 speakers and 2,000 attendees, and the appetite continues to grow.

From day one everyone has embraced Pint of Science, making it a sought-after event and a very promising method of science communication. It is amazing how many people are now approaching us, either to speak, help organize or even advertise the event. We are extremely grateful to all the people that have supported us, our sponsors, host bars, speakers and the Pint of Science International team and community who have helped us every step of the way. Pint of Science is growing everywhere - we invite you to join us in 2020. Look for the closest event near you on the website (https:// pintofscience.co.uk/locations/).

Laura Benzonana (D) 1* and Nikolaos Sgantzis² ${ }^{1}$ Director, Pint of Science Greece, Athens, Greece.

${ }^{2}$ Forensic DNA expert/Division of National Forensic DNA Database, Pint of Science Athens Coordinator, Athens, Greece.

*e-mail: laurabenzonana@gmail.com

Published online: 25 February 2020 https://doi.org/10.1038/s41563-020-0607-X

References

1. Paul, P. \& Motskin, M. Trends Immunol. 37, 268-271 (2016).

2. Davidson, C. Pint of Science https://pintofscience.co.uk/blog/pintof-science-the-past-the-present-and-the-future (2019).

\section{Acknowledgements}

We thank the members of the Greece team: N. Diogou, E. Grammatikopoulou, A. Morelas, T. Loukanari and M. Hatzidaki. We also thank E. Chabrol, international director, and P. Paul and M. Motskin, founders of Pint of Science. 